\title{
Effect of FYM and NPK on growth, yield and oil production of mustard under the agro-climatic condition of Tandojam- Pakistan
}

Javed Ahmed Abro', Maliha Habib ${ }^{2}$, Muhammad Iqbal Jakhro ${ }^{2 *}$, Fariha Maham3, Sher Amed ${ }^{2}$, Abdul Latif ${ }^{2}$, Abdul Qadir Gola ${ }^{4}$, Amanullah Abro' ${ }^{1}$, Gaji Bux Bugti ${ }^{5}$, Usama Nawaz ${ }^{2}$, Muhammad Anwar ${ }^{2}$ and Shahzad Ahmed Shahwani ${ }^{2}$

1. Department of Agronomy, Sindh Agriculture University, Tandojam, 70060-Pakistan

2. PARC, Balochistan Agricultural Research and Development Centre Brewery Road, Quetta-Pakistan

3. Sardar Bahadur Khan Women University Brewery Road, Quetta-Pakistan

4. Department of Horticulture, Sindh Agriculture University, Tandojam, 70060-Pakistan

5. Wheat Directorate Jaffarabad, Usta Mohammad, Balochistan-Pakistan

*Corresponding author's email: iqbal.jakhro@gmail.com

Citation

Javed Ahmed Abro, Maliha Habib, Muhammad Iqbal Jakhro, Fariha Maham, Sher Amed, Abdul Latif, Abdul Qadir Gola, Amanullah Abro, Gaji Bux Bugti, Usama Nawaz, Muhammad Anwar and Shahzad Ahmed Shahwani. Effect of FYM and NPK on growth, yield and oil production of mustard under the agro-climatic condition of TandojamPakistan. Pure and Applied Biology. Vol. 8, Issue 1, pp509-517. http://dx.doi.org/10.19045/bspab.2018.700210

\begin{tabular}{llll}
\hline \hline Received: 06/10/2018 & Revised: 05/12/2018 & Accepted: 10/12/2018 & Online First: 12/12/2018 \\
\hline
\end{tabular}

\section{Abstract}

In order to study the effect of FYM and NPK on growth, yield and oil production of mustard, Five treatments were formed including control $\mathrm{T}_{1}=$ Natural (Farmer practice), $\mathrm{T}_{2}=$ Recommended NPK 12080-40 kg ha-1, T $=$ FYM $1 \mathrm{t} \mathrm{ha}^{-1}+$ NPK $120-80-40 \mathrm{~kg} \mathrm{ha}^{-1}, \mathrm{~T}_{4}=\mathrm{FYM} 3 \mathrm{t} \mathrm{ha}^{-1}+\mathrm{NPK} 120-80-40 \mathrm{~kg} \mathrm{ha}^{-1}$, $\mathrm{T}_{5}=\mathrm{FYM} 5 \mathrm{t} \mathrm{ha}^{-1}+\mathrm{NPK} 120-80-40 \mathrm{~kg} \mathrm{ha}^{-1}$ and $\mathrm{T}_{6}=\mathrm{FYM} 7 \mathrm{t} \mathrm{ha}^{-1}+\mathrm{NPK} 120-80-40 \mathrm{~kg} \mathrm{ha}^{-1}$ results showed that significantly $(\mathrm{P}<0.05)$ of seed yield and mustard of oil content influenced through the FYM \& NPK levels. Results further showed that the mustard crop given recommended NPK 120-80-40 $\mathrm{kg} \mathrm{ha}^{-1}$ in crop performance with $134.33 \mathrm{~cm}$ plant height, 188.37 no of pods plant ${ }^{-1}, 11.31$ no of seeds pod ${ }^{-1}$, $3.42 \mathrm{~g}$ in seed index, $1510.21 \mathrm{~kg}$ seed production $\mathrm{ha}^{-1}$ and $31.10 \%$ oil content. However the minimum lowest crop performance was observed in control, where no fertilizer ware applied, having $128.33 \mathrm{~cm}$ plant height, 145.41 number of pods plant ${ }^{-1}, 8.12$ number of seeds pods ${ }^{-1}, 3.00 \mathrm{~g}$ seed index, $1325.14 \mathrm{~kg}$ seed yield production $\mathrm{ha}^{-1}$ and $26.35 \%$ content oil. It is concluded that mustard yield increase with NPK combined with FYM 120-80-40 + 7 ton FYM but 5 ton FYM combined with NPK120-80-40 was economic dose for mustard production. The oil production also increase at combined application of FYM and NPK fertilizers.

Keywords: FYM; Growth and yield; Mustard; NPK; Oil production

Introduction

Mustard (Brassica juncia L.) are important oilseed crops which rank third in vegetable oils after soybean and palm while second in oilseed proteins production after soybean in the world [1]. The global production of 
rapeseed-mustard (Brassica juncia L.) was $62.45 \mathrm{mt}$ from an acreage of $33.64 \mathrm{mha}$ with a total productivity of $18.56 \mathrm{q} / \mathrm{ha}$ [2]. Pakistan economy mainly based on agricultural production, inappropriately $80 \%$ edible oil was imported for consumption in 2012-13, as local edible oil production of 20 $\%$ of the domestic demand. During 2012-13 the overall edible oil was 3.069 million tons. Native edible oil production remained figure is 0.606 million tons though 2.502 million tons were import. In 2012-13 import bill stood at Rs. 241.936 billion. During 2013-14 in July and March 1.719 million tons edible oil valued Rs. 148633 billion imported. In 2013-14 local oil production was 0.606 million tons and overall edible oil availability through overall source was estimated 2.325 million tons in 2013-14 [3]. It plays significant role in the development of seed. An oil seed crop requires Sulphur comparatively higher than other nutrient and it is now being recognized as the fourth major element of the plant. Primary nutrient of plants are nitrogen, phosphorus and potassium. Phosphorus plays a vital role in photosynthesis, respiration, cell conclusion cell enlargement and several other processes in living plants [4]. Application of potassium upto $60 \mathrm{~kg} \mathrm{ha}^{-1}$ also significantly increased grain yields of Indian mustard. High potassium application of increase in grain yield reported by [5]. Seed yield and yield attributes of Indian mustard increased with increasing level of nitrogen and phosphorus upto 120 and $80 \mathrm{~kg} \mathrm{ha}^{-1}$ respectively. It was also reported in maizemustard sequence, FYM gave highest seed yield and quality of the oil [6]. Significant increase in protein and oil content in mustard seed due to application of $150 \mathrm{~kg} \mathrm{~N}$ ha $^{-1}$ compared to $50 \mathrm{~kg} \mathrm{~N} \mathrm{ha}^{-1}$ [7].

Thus, adequate nutrient supply increases the seed and oil yields by improving the setting pattern of siliquae on branches, number of siliquae per plant and other yield attributes.
Farmers most commonly use di ammonium phosphate that supplies only nitrogen and phosphorus. So, for obtaining maximum efficiency of added fertilizer, balanced fertilization to crops including use of potassium and micronutrients, is essential. Micronutrient helps in photosynthetic activities and proper utilization of nitrogen and phosphorus [8]. Application of nutrients and its management is crucial agronomic practice that has a profound influence on Indian mustard's (Brassica juncia L.) yield. The soil physico-chemical properties can be improved by application of Farm yard manure (FYM) which results in improvement of necessary nutrients; eventually the crop yields increases $[9,10]$. Indian mustard is more receptive to chemical fertilizers i.e. nitrogen and to some extent to sulfur, for better mustard production considering soil health. Day by day due to increasing prices of chemical fertilizers, there is urgent need to explore suitable substitute nutrients especially Nitrogen. The key to success is the assimilation of all possible nutrient sources for growing demand of oil seeds and by the more production of oil seed which lessen the load on the foreign exchange as oil import is costing highly. Addition of chemical fertilizers, Farm Yard Manure plus Biofertilizers could be a step forward, as they are low cost, highly nutritive for crops and inexhaustible. Some potential biofertilizers are Azospirillum and Azotobactor which are non-symbiotic bacteria, having the ability of adding Nitrogen to legumes by tapping nitrogen from air. The action of biofertilizers is subjective to be influenced with the addition of nutrients like Nitrogen. The present investigation was therefore investigated to know the effect of integrated nutrient management on mustard's (Brassica juncia L.) performance. The objectives of this study were to determine the effects of $\mathrm{K}$ with addition of different nutrients on 
mustard's attributing traits, quality parameters and yield.

\section{Materials and methods}

The research experiment was conduct at Student's experimental farm, Sindh Agriculture University, Tandojam-Pakistan during Rabi, 2016-17. Three (3) year old FYM used in experimental plot. Recommended dose of NPK will applied in each treatment. Following details are as under:

Experiment research design $=$ Randomized complete block design (RCBD)

Replication $=$ Three

Name of variety $=\mathrm{S}-9$

Plot size $=4 \mathrm{~m} \times 3 \mathrm{~m}=\left(12 \mathrm{~m}^{2}\right)$

Following six treatments of FYM and NPK levels

$\mathrm{T}_{1}=$ Farmer practice (Natural)

$\mathrm{T}_{2}=$ Recommended ratio of NPK 120-80-40 $\mathrm{kg} / \mathrm{ha}$

$\mathrm{T}_{3}=\mathrm{FYM} 1 \mathrm{t} \mathrm{ha}^{-1}+$ NPK $120-80-40 \mathrm{~kg} / \mathrm{ha}$

$\mathrm{T}_{4}=\mathrm{FYM} 3 \mathrm{t} \mathrm{ha}^{-1}+$ NPK $120-80-40 \mathrm{~kg} / \mathrm{ha}$

$\mathrm{T}_{5}=$ FYM $5 \mathrm{t} \mathrm{ha}^{-1}+$ NPK $120-80-40 \mathrm{~kg} / \mathrm{ha}$

$\mathrm{T}_{6}=\mathrm{FYM} 7 \mathrm{t} \mathrm{ha}^{-1}+$ NPK $120-80-40 \mathrm{~kg} / \mathrm{ha}$

\section{Observations to be recorded}

1. Height of plant $\mathrm{cm}$

2. Nos of pods per plant

3. Number of seeds per pod

4. Seed index in 1000 seed wt. (g)

5. Seed yield production $\mathrm{kg} / \mathrm{ha}$

6. Oil content $(\%)$

\section{Observations recording methodology}

Height of plant cm: Measure at heading stage of crop through measuring tape from bottom to tip of plant in labeled plants in individual treatment.

\section{Nos of Pods per plant}

The pods counted per plant was at maturity stage of crop in labeled plants in individual treatment. The sum were then divided with the total number of plants.

\section{No of seeds per pod}

Selected labeled plant from the field at maturity of the crop plants than counted the seeds each pods from selected plant.
Seed index in $1000 \mathrm{~g}$ seeds

Recorded manually 1000 seeds weight through including in individual treatment and weighted observed seed index grams.

\section{Seed yield production $\mathrm{kg} / \mathrm{ha}$}

After harvesting of crop, the total seed production of each treatment in all replications were weighted and divided by number of replications to achieve the mean seed yield $(\mathrm{kg})$ plot $^{-1}$. Later, on the basis of seed yield plot $^{-1}$, the seed yield $\left(\mathrm{kg} \mathrm{ha}^{-1}\right)$.

\section{Oil content \%}

The oil content percentage was recorded under the laboratory of oil seed extracting from lab instruments first the seeds of mustard were taken and grinded by a grinding machine. The $3 \mathrm{~g}$ of grinded seeds sample was weighed and put into the filter paper than the seed sample was put into the extractor tube of soxhlet machine with the help of the pair of the tong than the distillation flask was filled with the petroleum ethyl solution. The soxhlet apparatus was turned on and the temperature was raised gradually.

\section{Cultural practices}

Nitrogen $\left(120 \mathrm{~kg} \mathrm{ha}^{-1}\right)$ was split applied at sowing, $2^{\text {nd }}$ and $3^{\text {rd }}$ irrigations as per treatments in the form of Urea. All P (at varying levels) was applied in the form of single super phosphate at the time of sowing.

\section{Statistical analysis}

Analyzed the research data by used computer software Statistix 8.1 version [11]. The various differentiate along with treatments were compared through least significant various (LSD) test where compulsory.

\section{Results and discussion}

The experiment was conducted during 201617. Five treatments were formed including a $\mathrm{T}_{1}=$ Control (Natural), $\mathrm{T}_{2}=$ Recommended dose of NPK 120-80-40 kg ha' ${ }^{-1} \mathrm{~T}_{3}=$ FYM 1 $\mathrm{t} \mathrm{ha}^{-1}+$ NPK 120-80-40 kg ha-1, $\mathrm{T}_{4}=\mathrm{FYM}$ 
$3 \mathrm{t} \mathrm{ha}^{-1}+$ NPK 120-80-40 kg ha ${ }^{-1}, \mathrm{~T}_{5}=\mathrm{FYM}$ $5 \mathrm{t} \mathrm{ha}^{-1}+$ NPK 120-80-40 $\mathrm{kg} \mathrm{ha}^{-1}$ and $\mathrm{T}_{6}=$ FYM 7 t ha $^{-1}+$ NPK 120-80-40 kg ha ${ }^{-1}$ at Sindh Agriculture University, Tandojam Pakistan. The observations some characters of economy output value were following recorded: height of plant $\mathrm{cm}$, no of pods/plant, no of seeds pod $^{-1}$, seed index $1000 \mathrm{~g}$ seed wt., seed yield production $\mathrm{kg} \mathrm{ha}^{-}$ ${ }^{1}$ and oil content (\%).This chapter contains the data (Table 1-6) along with the results interpretation in headings.

Height of plant cm: Data observed to height of mustard plant (Variety S-9) as prejudiced by different approaches of FYM $\&$ NPK levels applied shown in table-1. The variance analysis (Appendix-I) established significant $(\mathrm{P}<0.005)$ result FYM \& NPK levels on mustard's plant height. Height of plant $(145.38 \mathrm{~cm})$ observed fertilized in plots with FYM 7t ha ${ }^{-1}$ + NPK 120-80-40 kg ha ${ }^{-1}$, followed by normal height of plant 144.00 $\mathrm{cm}, 141.00 \mathrm{~cm}$ and $139.22 \mathrm{~cm}$ achieved in plots given FYM 1t ha-1 + NPK 120-80-40 $\mathrm{kg} \mathrm{ha}^{-1}$, FYM 3t ha ${ }^{-1}+$ NPK 120-80-40 kg $\mathrm{ha}^{-1}$ and FYM 5t ha ${ }^{-1}+$ NPK 120-80-40 kg $\mathrm{ha}^{-1}$ respectively. Yet height of plant reduced considerably to $134.33 \mathrm{~cm}$ when crop was supplied with recommended NPK 120-80-40 $\mathrm{kg}$ per ha respectively. However less height of plant $(128.33 \mathrm{~cm})$ was observed in control plots, where fertilizer didn't applied. Way to scientific logic the plots receiving FYM 7t $\mathrm{ha}^{-1}+$ NPK 120-80-40 $\mathrm{kg} \mathrm{ha}^{-1}$ at sowing was moderate level so far the height of plant is concerned.

Table 1. Height of plant $\mathrm{cm}$ of mustard as resulted by FYM and NPK

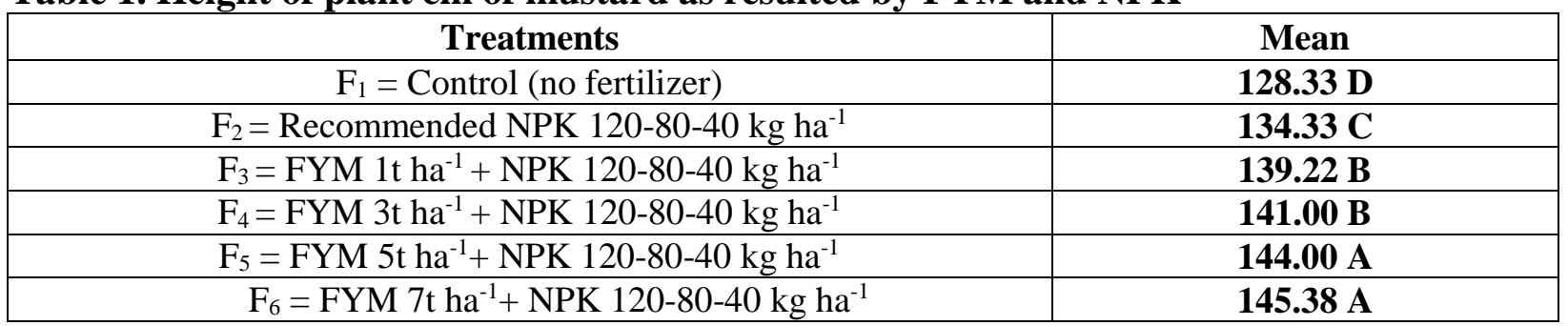

S.E. $\pm=2.2420$

LSD $0.05=4.9954$

\section{Number of pods per plant}

The number of pods /plant has linear effect on seed yield per plant production under control soil, climatic \& management conditions. Results are relative to no of plant per pods of mustard as increased through FYM and NPK doses are given away in table-2. Analysis of difference (AppendixII) suggested that no of plant /pods in plant were significantly $(\mathrm{P}<0.05)$ influenced by FYM and NPK fertilizer levels. Maximum no of pods were (303.23) plant $^{-1}$ recorded in given plots FYM 7t ha ${ }^{-1}+$ NPK 120-80-40 $\mathrm{kg} \mathrm{ha}{ }^{-1}$, followed by $293.34,265.44$ and
212.46 pods plant $^{-1}$ observed in plots given FYM 1t ha-1 + NPK 120-80-40 kg ha ${ }^{-1}$, FYM 3t ha- ${ }^{-1}+$ NPK 120-80-40 kg ha ${ }^{-1}$ and FYM 5t $\mathrm{ha}^{-1}$ NPK 120-80-40 kg/ha respectively. The no of pods plant ${ }^{-1}$ declined noticeably to 188.37 plant $^{-1}$ in plots given recommended NPK 120-80-40 $\mathrm{kgha}^{-1}$, respectively. However the less pods /plant (145.41) was recorded in (control) no fertilizer was applied. It was observed that plots receiving FYM 7t ha ${ }^{-1}+$ NPK 120-80$40 \mathrm{~kg} \mathrm{ha}^{-1}$ at time of sowing was an optimum dose so far number of pods plant $^{-1}$ of mustard concerned. 
Table 2. Number of pods per plant of mustard as resulted by FYM and NPK

\begin{tabular}{|c|c|}
\hline Treatments & Mean \\
\hline F $_{1}=$ Control (no fertilizer) & $\mathbf{1 4 5 . 4 1 ~ D ~}$ \\
\hline F $_{2}=$ Recommended NPK $120-80-40 \mathrm{~kg} \mathrm{ha}^{-1}$ & $\mathbf{1 8 8 . 3 7 ~ C}$ \\
\hline F $_{3}=$ FYM $1 \mathrm{t} \mathrm{ha}^{-1}+$ NPK $120-80-40 \mathrm{~kg} \mathrm{ha}^{-1}$ & $\mathbf{2 1 2 . 4 6 ~ B ~}$ \\
\hline F $_{4}=$ FYM $3 \mathrm{t} \mathrm{ha}^{-1}+$ NPK $120-80-40 \mathrm{~kg} \mathrm{ha}^{-1}$ & $\mathbf{2 6 5 . 4 4 ~ B}$ \\
\hline F $_{5}=$ FYM $5 \mathrm{t} \mathrm{ha}^{-1}+$ NPK $120-80-40 \mathrm{~kg} \mathrm{ha}^{-1}$ & $\mathbf{2 9 3 . 3 4 ~ A}$ \\
\hline F $_{6}=$ FYM $7 \mathrm{t} \mathrm{ha}^{-1}+$ NPK $120-80-40 \mathrm{~kg} \mathrm{ha}^{-1}$ & $\mathbf{3 0 3 . 2 3 ~ A}$ \\
\hline
\end{tabular}

S.E. $\pm=41.539$

LSD $0.05=92.555$

\section{Number of seeds pod $^{-1}$}

The number of seeds pod $^{-1}$ is generally influenced by the genetic make of different crop varieties, but the increased of crop management and proper input application is also of prime importance. The data in regards to number of seeds pod $^{-1}$ of mustard as affected by various FYM and NPK levels showed in table-3. Analysis of the variance (Appendix-III) showed significantly $(\mathrm{P}<0.005)$ of seeds per pod by FYM \& NPK levels. The highest no of seeds pod ${ }^{-1}(18.23)$ was observed in plots given soil applied FYM 7t ha ${ }^{-1}+$ NPK 120-80-40 kg ha-1, followed by $15.33,14.46$ and 13.16 seeds pod $^{-1}$ observed in plots supplied with FYM 1t ha $\mathrm{ha}^{-1}+$ NPK 120-80-40 kg ha-1 , FYM 3t $\mathrm{ha}^{-1}+$ NPK 120-80-40 kg ha-1 and FYM 5t $\mathrm{ha}^{-1}+$ NPK 120-80-40 kg/ha respectively. However, no of seed /pods decreased 11.31 in plot given recommended NPK 120-80-40 $\mathrm{kg} / \mathrm{ha}$, respectively. However, lowest no of seed pod $^{-1}$ (8.12) observed in without fertilizer plots. It was observed that plots receiving FYM 7t ha ${ }^{-1}+$ NPK 120-80-40 $\mathrm{kg} / \mathrm{ha}$ at time of sowing time was moderate level so afar the number of seeds pod $^{-1}$ of mustard is concerned.

Table 3. Number of seed per pod of mustard as affected through FYM and NPK

\begin{tabular}{|c|c|}
\hline Treatments & Mean \\
\hline $\mathrm{F}_{1}=$ Control (no fertilizer) & $\mathbf{8 . 1 2}$ D \\
\hline $\mathrm{F}_{2}=$ Recommended NPK 120-80-40 $\mathrm{kg} \mathrm{ha}^{-1}$ & $\mathbf{1 1 . 3 1 ~ C}$ \\
\hline $\mathrm{F}_{3}=$ FYM $1 \mathrm{t} \mathrm{ha}{ }^{-1}+$ NPK $120-80-40 \mathrm{~kg} \mathrm{ha}^{-1}$ & $\mathbf{1 3 . 1 6 ~ B ~}$ \\
\hline $\mathrm{F}_{4}=$ FYM $3 \mathrm{t} \mathrm{ha}+$ NPK $120-80-40 \mathrm{~kg} \mathrm{ha}^{-1}$ & $\mathbf{1 4 . 4 6 ~ B ~}$ \\
\hline $\mathrm{F}_{5}=$ FYM $5 \mathrm{t} \mathrm{ha}^{-1}+$ NPK $120-80-40 \mathrm{~kg} \mathrm{ha}^{-1}$ & $\mathbf{1 5 . 3 3 ~ A}$ \\
\hline $\mathrm{F}_{6}=$ FYM $7 \mathrm{t} \mathrm{ha}^{-1}+$ NPK $120-80-40 \mathrm{~kg} \mathrm{ha}^{-1}$ & $\mathbf{1 8 . 2 3 ~ \mathbf { A }}$ \\
\hline
\end{tabular}

S.E. $\pm=0.8354$

\section{LSD $0.05=1.8613$}

\section{Seed index 1000 weight in $\mathrm{g}$}

Seed index is seemingly a measureable trait, but it initially denotes the value of seed plant being evaluated. Seed index of mustard as affected FYM and NPK levels are showed in table no. 4. Analysis of different AppendixIV, expressed seed index was significantly $(\mathrm{P}<0.05)$ varied of different levels of FYM and NPK. The highest seed index g (7.18) was applied fertilized with FYM 7t ha ${ }^{-1}+$ NPK 120-80-40 kg ha-1, followed by seed index data $6.00 \mathrm{~g}, 4.47 \mathrm{~g}$ and $4.38 \mathrm{~g}$ observed in plots applied with FYM 1t /ha + NPK 120-80-40 kg /ha, FYM 3t ha ${ }^{-1}+$ NPK 120-80-40 kg ha ${ }^{-1}$ and FYM 5t ha ${ }^{-1}+$ NPK $120-80-40 \mathrm{~kg} \mathrm{ha}^{-1}$ respectively. However, seed index decreased to $3.42 \mathrm{~g}$ in plots given recommended NPK 120-80-40 kg ha respectively. Seed index $(3.00 \mathrm{~g})$ was recorded in control plots. It was observed that plots receiving FYM $7 \mathrm{t} \mathrm{ha}^{-1}+\mathrm{NPK} 120-$ $80-40 \mathrm{~kg} \mathrm{ha}^{-1}$ at sowing was an optimum fertilizers dose so far the mustard sex index is concerned. 
Table 4. Seed index $1000 \mathrm{~g}$ seed wt. of mustard as affected through FYM and NPK

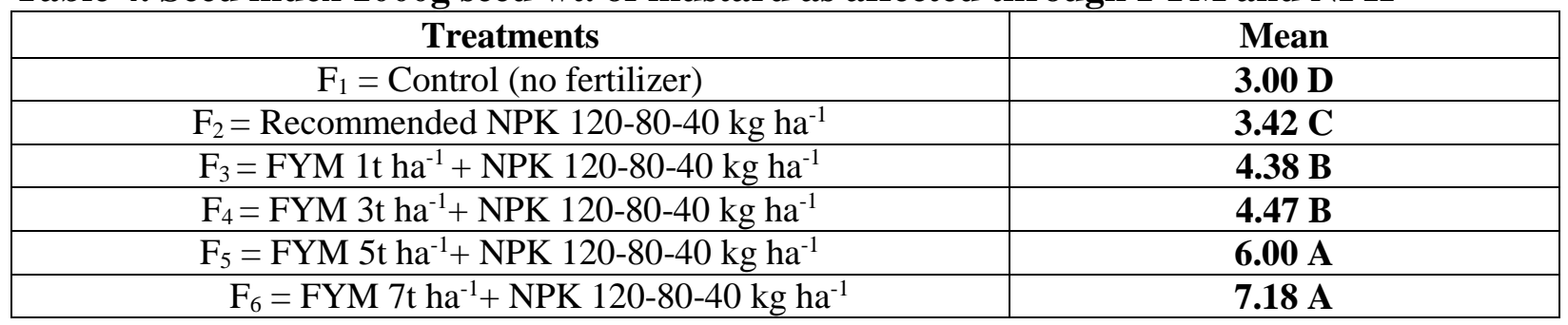

S.E. $\pm=0.5485$

LSD $0.05=1.2220$

\section{Seed yield ( $\mathrm{kg} \mathrm{ha}^{-1}$ )}

The results in relation to seed yield $\mathrm{ha}^{-1}$ of mustard variety "S-9" as affected by different FYM and NPK levels are presented in Table-5 and its analysis of variance as Appendix-V. The analysis of variance demonstrated that seed yield ha ${ }^{-1}$ was significantly $(\mathrm{P}<0.05)$ influenced by $F Y M$ and NPK levels. The highest seed yield of $2090.47 \mathrm{~kg} \mathrm{ha}^{-1}$ was obtained from the given plots FYM 7t ha-1 + NPK 120-80-40 kg ha-1, followed by $1805.27,1711.00$ and $16.31 \mathrm{~kg}$ seed yield ha $^{-1}$ achieved in plots fertilized with FYM 1t ha-1 + NPK 120-80-40 kg ha-1, FYM 3t ha- ${ }^{-1}$ NPK 120-80-40 kg ha-1 and
FYM 5t ha ${ }^{-1}+$ NPK 120-80-40 kg ha-1 respectively. However, seed yield production $\mathrm{kg}$ per ha much reduced 1510.21 $\mathrm{kg} \mathrm{ha}{ }^{-1}$ obtained in plots given recommended NPK $120-80-40 \quad \mathrm{~kg} \mathrm{ha}^{-1}$ respectively. The minimum seed yield production $\mathrm{kg} \mathrm{ha}^{-1}$ (1325.14) was uptake in control plots, where is no fertilizers ware applied. It was concluded that plots receiving FYM 7t ha ${ }^{-1}+$ NPK 120-80-40 kg $\mathrm{ha}^{-1}$ at sowing was an optimum level so far seed yield per hector of mustard is concerned.

Table 5. Seed yield $\left(\mathrm{kg} \mathrm{ha}^{-1}\right)$ of mustard as affected by FYM and NPK

\begin{tabular}{|c|c|}
\hline Treatments & Mean \\
\hline $\mathrm{F}_{1}=$ Control (no fertilizer) & $1325 \mathrm{D}$ \\
\hline $\mathrm{F}_{2}=$ Recommended NPK 120-80-40 $\mathrm{kg} \mathrm{ha}^{-1}$ & $1510 \mathrm{C}$ \\
\hline $\mathrm{F}_{3}=\mathrm{FYM} 1 \mathrm{t} \mathrm{ha}^{-1}+$ NPK $120-80-40 \mathrm{~kg} \mathrm{ha}^{-1}$ & $1631 \mathrm{~B}$ \\
\hline $\mathrm{F}_{4}=\mathrm{FYM} 3 \mathrm{t} \mathrm{ha}^{-1}+$ NPK $120-80-40 \mathrm{~kg} \mathrm{ha}^{-1}$ & $1711 \mathrm{~B}$ \\
\hline $\mathrm{F}_{5}=\mathrm{FYM} 5 \mathrm{t} \mathrm{ha}^{-1}+\mathrm{NPK} 120-80-40 \mathrm{~kg} \mathrm{ha}^{-1}$ & $1805 \mathrm{~A}$ \\
\hline $\mathrm{F}_{6}=\mathrm{FYM} 7 \mathrm{t} \mathrm{ha}{ }^{-1}+$ NPK $120-80-40 \mathrm{~kg} \mathrm{ha}^{-1}$ & $2090 \mathrm{~A}$ \\
\hline
\end{tabular}

S.E. $\pm=95.089$

LSD $0.05=211.87$

\section{Oil content $(\%)$}

The oil content percentage in (Brassica junacea L.) as affected by levels of FYM and NPK is recorded in Table- 6 and its analysis of variance as Appendix-XI. The analysis of variance suggested that FYM and NPK levels in different split doses showed value significantly $(\mathrm{P}<0.05)$ on percentage of oil content. Data showed in table 6. That higher amount of oil content $(40.36 \%)$ was observed in crop receiving FYM $7 \mathrm{t} \mathrm{ha}^{-1}+$ NPK 120-80-40 kg ha ${ }^{-1}$ followed by oil contents of $38.15 \%, 36.15 \%$ and $35.00 \%$ recorded from the crop given FYM $1 \mathrm{t} \mathrm{ha} \mathrm{h}^{-1}+$ NPK 120-80-40 kg ha', FYM 3t ha-1 + NPK 120-80-40 kg ha-1 and FYM 5t ha-1 + NPK 120-80-40 kg ha-1, respectively. The oil content decreased to $31.10 \%$ when recommended NPK 120-80-40 kg ha-1 were applied, respectively. However, minimum content oil (26.35\%) obtained in control, where is no fertilizer ware applied. It was noted that plots receiving FYM $7 \mathrm{t} \mathrm{ha}^{-1}+$ NPK 120-80-40 kg ha-1 at sowing was 
optimum fertilizer dose far the oil content

percentage ha ${ }^{-1}$ of mustard is concerned.

Table 6. Oil content (\%) of mustard as affected by FYM and NPK

\begin{tabular}{|c|c|}
\hline Treatments & Mean \\
\hline F $_{1}=$ Control (no fertilizer) & 26.35 D \\
\hline F $_{2}=$ Recommended NPK 120-80-40 $\mathrm{kg} \mathrm{ha}^{-1}$ & $\mathbf{3 1 . 1 0 ~ C}$ \\
\hline F $_{3}=$ FYM $1 \mathrm{t} \mathrm{ha}^{-1}+$ NPK $120-80-40 \mathrm{~kg} \mathrm{ha}^{-1}$ & $\mathbf{3 5 . 0 0 ~ B}$ \\
\hline $\mathrm{F}_{4}=$ FYM $3 \mathrm{t} \mathrm{ha}^{-1}+$ NPK $120-80-40 \mathrm{~kg} \mathrm{ha}^{-1}$ & $\mathbf{3 6 . 1 5 ~ B}$ \\
\hline F $_{5}=$ FYM $5 \mathrm{t} \mathrm{ha}^{-1}+$ NPK $120-80-40 \mathrm{~kg} \mathrm{ha}^{-1}$ & $\mathbf{3 8 . 1 5 ~ A}$ \\
\hline F $_{6}=$ FYM $7 \mathrm{t} \mathrm{ha}^{-1}+$ NPK $120-80-40 \mathrm{~kg} \mathrm{ha}^{-1}$ & $\mathbf{4 0 . 3 6 ~ A}$ \\
\hline
\end{tabular}

S.E. $\pm=1.0193$

LSD $0.05=2.2711$

The existing oilseed production in the country is far less than the domestic requirement and it is essential to develop advanced crop management practices and by balancing nutrients [12]. The results showed that growth, seed yield and oil content significantly $(\mathrm{P}<0.05)$ mustard crop effected by FYM \& NPK levels. Fertilized mustard with FYM 7t ha-1 + NPK 120-80-40 kg ha-1 ranked $1^{\text {st }}$ with, $145.38 \mathrm{~cm}$ plant height, 303.23 number of pods plant $^{-1}, 18.23$ number of seeds pod $^{-1}, 7.18 \mathrm{~g}$ seed index, $2090 \mathrm{~kg}$ seed yield $\mathrm{ha}^{-1}$ and $40.36 \%$ oil content. The mustard crop getting FYM 5t $\mathrm{ha}^{-1}+$ NPK 120-80-40 kg ha-1 with 144.00 $\mathrm{cm}$ plant height, 193.34 number of pods plant $^{-1}, 15.33$ number of seeds pod $^{-1}, 6.00 \mathrm{~g}$ seed index, $1805 \mathrm{~kg}$ seed yield $\mathrm{ha}^{-1}$ and $38.15 \%$ oil content. The crop provided with FYM 3t ha ${ }^{-1}+$ NPK 120-80-40 kg ha-1 with $141.00 \mathrm{~cm}$ plant height, 265.44 numbers of pods per plant, 14.46 numbers of seeds per pod, $4.47 \mathrm{~g}$ seed index, $1711 \mathrm{~kg}$ seed yield $\mathrm{ha}^{-1}$ and $36.15 \%$ content oil. Mustard crop applied FYM 1t $\mathrm{ha}^{-1}+$ NPK 120-80-40 kg $\mathrm{ha}^{-1}$ with $139.22 \mathrm{~cm}$ plant height, 212.46 numbers of pods plant ${ }^{-1}, 13.16$ number of seeds pod ${ }^{-1}, 4.38 \mathrm{~g}$ seed index, $1631 \mathrm{~kg}$ seed yield $\mathrm{ha}^{-1}$ and $35.00 \%$ oil content. The effect further showed that the mustard crop received recommended NPK 120-80-40 kg $\mathrm{ha}^{-1}$ in crop performance with $134.33 \mathrm{~cm}$ plant height, 188.37 number of pods plant $^{-1}$, 11.31 number of seeds pod $^{-1}, 3.42 \mathrm{~g}$ seed index, $1510 \mathrm{~kg}$ seed yield $\mathrm{ha}^{-1}$ and $31.10 \%$ oil content. However, the minimum lowest crop performance was observed in control plots, wherever no manure was applied, having $128.33 \mathrm{~cm}$ plant height, 145.41 number of pods plant $^{-1}, 8.12$ number of seeds pod $^{-1}, 3.00 \mathrm{~g}$ seed index, $1325 \mathrm{~kg}$ seed yield $\mathrm{ha}^{-1}$ and $26.35 \%$ oil content. It is concluded that mustard yield increase with NPK combined with FYM 120-80-40 + 7 ton FYM but 5 ton FYM combined with NPK 120-80-40 was economic dose for mustard production. The oil production also increased at combined application of FYM and NPK fertilizers. These results are further supported by [13] under water stress environment the foliar appliance of fertilizers is most efficient to maintain the crop growth. [14] accounted that increasing doses of potassium fertilizers improved the seed yield and other agronomic parameters. In the same way, [15] for attaining higher seed mustard yields $80 \mathrm{~kg} \mathrm{~K} \mathrm{~K}_{2} \mathrm{O} \mathrm{ha}^{-1}$ is recommended the results were potentially better with the application of both soil and foliar Potassium as contrast to $\mathrm{K}$ application through soil or foliar appliance only. [16] reported with enhancing $\mathrm{k}$ levels that mustard seed yield increased also enhances. The findings of [17] presented highest seed production of $2085 \mathrm{~kg} \mathrm{ha}^{-1}$ in mustard is gained by the appliance of $60 \mathrm{~kg} \mathrm{~K}_{2} \mathrm{O} \mathrm{ha}{ }^{-1}$, $3.48 \%$ was higher than the control yield. [18] tested $\mathrm{K}$ in different levels with examined agronomical parameters i.e., seed yield, growth and oil contents of canola with 
attained seed production of $3473 \mathrm{~kg} \mathrm{ha}^{-1}$ in dose of $\mathrm{K} 150 \mathrm{~kg} \mathrm{ha}^{-1}$. But, mustard responded considerably through foliar application of $\mathrm{K}$ for growth and seed yield. [19] has obtained $3473 \mathrm{~kg} \mathrm{ha}^{-1}$ production of mustard seed yield with K $150 \mathrm{ha}^{-1}$, while [20] reported enhancement split appliance of Potassium and additional essential elements by foliar application. [21] specified $60 \mathrm{~kg}$ $\mathrm{K}_{2} \mathrm{O}$ ha $^{-1}$ through soil showed most favorable with enhance seed yield. [22] accounted that $\mathrm{K}$ application demonstrated optimistic influence on yield of mustard and cost advantage ratio were wonderful when $\mathrm{K}$ fertilizer applied over rest of fertilizer mixture. Research regained from the past investigations are fully harmony with conclusions of current finding. It is recommended that foliar application of $\mathrm{K}$ is very advantageous somewhat to enhance quantity of potassium application applied through soil. Therefore, to fulfill the crop necessities foliar application of $\mathrm{K}$ is more recommended as compared to application of Potassium through soil.

\section{Conclusions}

It is concluded that Mustard yield increased with NPK combined with FYM 120-80-40 + 7 ton FYM but 5 ton FYM combined with NPK 120-80-40 was economic dose for mustard production .The oil production also increased at combined application of FYM and NPK fertilizers..

\section{Authors' contributions}

Conceived and designed the experiments: JA Abro, M Habib \& MI Jakhro, Performed the experiments: JA Abro, A Abro, AQ Gola \& GB Bugti, Analyzed the data: S Ahmed, A Latif, SA Shahwani \& M Anwar, Contributed reagents/ materials/ analysis tools: U Nawaz, F Maham \& M Habib, Wrote the paper: JA Abro, M Habib \& MI Jakhro.

\section{References}

1. USDA (2011). Foreign Agriculture Service, Oilseeds: World markets and trade. Circular Series, FOP 1-11 p. January.

2. Food and Agriculture Organization Statistics (2011). (http:// faostat.com/).

3. GOP (2008). Agricultural statistics of Pakistan. Ministry of Food, Agriculture and Livestock (Economic Wing), Islamabad.

4. Katyayan A (2010). Manure, Fertilizers and biofertilizers. Fundamentals of Agri 11(1): 232-234.

5. Tiwari DD, Pandey SB and Dubey MK (2012). Effect of potassium application on yield and quality characteristics of pigeon pea (Cajanus cajan) and mustard (Brassica juncea L. Czern) crops in central plain zone of Uttar Pradesh. Inter Potash Inst 31: 16-20.

6. Shekhawat K, Rathore SS, Premi OP, Kandpal BK and Chauhan JS (2012). Advances in agronomic management of Indian mustard [B. juncea (L.) Czern \& Coss.]: An Overview. Intern J Agron doi:10.1155/2012/408284.

7. Singh Y, Singh T, Singh S and Rajput PK (2010). Effect of nutrient management on yield, quality and economics of irrigated Indian mustard (Brassica juncea). Indian J Agri Sci. 80(8): 691-694.

8. Verma KC and Baigh MA (2012). Response of phosphorus and molybdenum on yield and quality attributing characters of Indian mustard (Brassica juncea. Czern \& Coss). The Bioscan 7(3): 437-440.

9. Bhatia KS and Shukla KK (1982). Effect of continuous application of fertilizer and manure on some physical properties of eroded alluvial soils. 30(1): 33-36.

10. Singh AK and Kumar P (2009). Nutrient management in rainfed dryland agro ecosystem in the impending climate change scenario. Agri Situation India 66(5): 265-270. 
11. Statistix (2006). Analytical Software. Statistix 8.1 User's Manual. Analytical Software, Tallahssee, Florida.

12. Oad FC, Buriro UA and Agha SK (2004). Effect of organic and inorganic fertilizer application on maize fodder production. Asian J Plant Sci 3(3): 375377.

13. Slathia S, Sharma A \& Choudhary S (2012). Influence of exogenously applied epibrassinolide and putrescine on protein content, antioxidant enzymes and lipid peroxidation in lycopersicon esculentum under salinity stress. Ameri $J$ of plant Sci 3(6): 714-720.

14. Gusmao M, Siddique KHM, Flower K, Nesbitt H and Veneklaas KJ (2012). Water deficit during the reproductive period of grass pea (Lathyrus sativus L.) reduced grain yield but maintained seed size. J Agro \& Crop Sci 198(6): 430441.

15. Mondal, S, Chakraborty D, Tomar RK, Singh R, Garg RN, Aggarwal P, Sidhu GS and Behra UK (2013). Tillage and residue management effect on soil hydro physical environment under pigeon pea (Cajanus cajan)-wheat (Triticum aestivum) rotation. Indian $J$ of Agri Sci. 83(4): 502-507.

16. Vassilina $\mathrm{T}$, Umbetov $\mathrm{A}$ and Vassilina G (2012). Some aspects of mineral and organic nutrition for improved yield and oil contents of mustard (Brassica juncea). J Bulgarian of Agri Sci 18(6): 924-928.
17. Arya RL, Varshney JG and Kumar L (2007). Effect of integrated nutrient application in chickpea+mustard intercropping system in the semi-arid tropics of north India. J Communi in soil sci and plant analysis 38(1-2): 229240.

18. Khan MU, Qasim $M$ and Khan IU (2007). Effect of integrated nutrient management on crop yields in ricewheat cropping system. J Agri 23(2): 104-109.

19. Brar BS, Jagdeep S, Gurbir S and Gurpreet K (2015). Effects of long term application of inorganic and organic fertilizers on soil organic carbon and physical properties in maize-wheat rotation. J Agro 20(1): 273-279.

20. Sieling K and Beims S (2016). Effects of $15 \mathrm{~N}$ split-application on soil and fertilizer $\mathrm{N}$ uptake of barley, oilseed rape and wheat in different cropping systems. J of agro and crop sci 193(1): 10-20.

21. Lonea PM and Khan NA (2016). The effects of rate and timing of $\mathrm{N}$ fertilizer on growth, photosynthesis, $\mathrm{N}$ accumulation and yield of mustard, (Brassica juncea) subjected to defoliation. Enviro and Experil Botany 60(3): 318-323.

22. Singh B, Singh BP and Cowie AL (2010). Characterization and evaluation of biochars for their application as a soil amendment. Austra J Soil Res 48(1): 516-525. 